\title{
ABCB subfamily (version 2019.4) in the IUPHAR/BPS Guide to Pharmacology Database
}

\author{
Mary Vore ${ }^{1}$
}

1. University of Kentucky, USA

\begin{abstract}
The ABCB subfamily is composed of four full transporters and two half transporters. This is the only human subfamily to have both half and full types of transporters. ABCB1 was discovered as a protein overexpressed in certain drug resistant tumor cells. It is expressed primarily in the blood brain barrier and liver and is thought to be involved in protecting cells from toxins. Cells that overexpress this protein exhibit multi-drug resistance [4].
\end{abstract}

\section{Contents}

This is a citation summary for ABCB subfamily in the Guide to Pharmacology database (GtoPdb). It exists purely as an adjunct to the database to facilitate the recognition of citations to and from the database by citation analyzers. Readers will almost certainly want to visit the relevant sections of the database which are given here under database links.

GtoPdb is an expert-driven guide to pharmacological targets and the substances that act on them. GtoPdb is a reference work which is most usefully represented as an on-line database. As in any publication this work should be appropriately cited, and the papers it cites should also be recognized. This document provides a citation for the relevant parts of the database, and also provides a reference list for the research cited by those parts.

Please note that the database version for the citations given in GtoPdb are to the most recent preceding version in which the family or its subfamilies and targets were substantially changed. The links below are to the current version. If you need to consult the cited version, rather than the most recent version, please contact the GtoPdb curators.

\section{Database links}

ABCB subfamily

http://www.guidetopharmacology.org/GRAC/FamilyDisplayForward?familyld=152

Transporters

MDR1, PGP1(ABCB1)

http://www.guidetopharmacology.org/GRAC/ObjectDisplayForward?objectld=768

TAP1(ABCB2)

http://www.guidetopharmacology.org/GRAC/ObjectDisplayForward?objectld=769

TAP2(ABCB3)

http://www.guidetopharmacology.org/GRAC/ObjectDisplayForward?objectld=770 


\section{PGY3(ABCB4)}

http://www.guidetopharmacology.org/GRAC/ObjectDisplayForward?objectld=771 ABCB5

http://www.guidetopharmacology.org/GRAC/ObjectDisplayForward?objectld=772 MTABC3(ABCB6)

http://www.guidetopharmacology.org/GRAC/ObjectDisplayForward?objectld=773

ABC7(ABCB7)

http://www.guidetopharmacology.org/GRAC/ObjectDisplayForward?objectld=774

MABC1(ABCB8)

http://www.guidetopharmacology.org/GRAC/ObjectDisplayForward?objectld=775 TAPL(ABCB9)

http://www.guidetopharmacology.org/GRAC/ObjectDisplayForward?objectld=776 MTABC2(ABCB10)

http://www.guidetopharmacology.org/GRAC/ObjectDisplayForward?objectld=777 ABC16(ABCB11)

http://www.guidetopharmacology.org/GRAC/ObjectDisplayForward?objectld=778

\section{References}

1. Bayeva M, Khechaduri A, Wu R, Burke MA, Wasserstrom JA, Singh N, Liesa M, Shirihai OS, Langer NB and Paw BH et al.. (2013) ATP-binding cassette B10 regulates early steps of heme synthesis.Circ. Res. 113: 279-87 [PMID:23720443]

2. Byrne JA, Strautnieks SS, Mieli-Vergani G, Higgins CF, Linton KJ and Thompson RJ. (2002) The human bile salt export pump: characterization of substrate specificity and identification of inhibitors. Gastroenterology 123: 1649-58 [PMID:12404239]

3. Chavan H, Li F, Tessman R, Mickey K, Dorko K, Schmitt T, Kumer S, Gunewardena S, Gaikwad N and Krishnamurthy P. (2015) Functional coupling of ATP-binding cassette transporter Abcb6 to cytochrome P450 expression and activity in liver. J. Biol. Chem. 290: 7871-86 [PMID:25623066]

4. Dean M, Hamon $Y$ and Chimini G. (2001) The human ATP-binding cassette (ABC) transporter superfamily. J. Lipid Res. 42: 1007-17 [PMID:11441126]

5. Demirel Ö, Jan I, Wolters D, Blanz J, Saftig P, Tampé R and Abele R. (2012) The lysosomal polypeptide transporter TAPL is stabilized by interaction with LAMP-1 and LAMP-2. J. Cell. Sci. 125: 4230-40 [PMID:22641697]

6. Elliott AM and Al-Hajj MA. (2009) ABCB8 mediates doxorubicin resistance in melanoma cells by protecting the mitochondrial genome. Mol. Cancer Res. 7: 79-87 [PMID:19147539]

7. Garzel B, Yang H, Zhang L, Huang SM, Polli JE and Wang H. (2014) The role of bile salt export pump gene repression in drug-induced cholestatic liver toxicity. Drug Metab. Dispos. 42: 318-22 [PMID:24335466]

8. Helias V, Saison C, Ballif BA, Peyrard T, Takahashi J, Takahashi H, Tanaka M, Deybach JC, Puy H and Le Gall $M$ et al.. (2012) ABCB6 is dispensable for erythropoiesis and specifies the new blood group system Langereis. Nat. Genet. 44: 170-3 [PMID:22246506]

9. Hirschfield GM, Chapman RW, Karlsen TH, Lammert F, Lazaridis KN and Mason AL. (2013) The genetics of complex cholestatic disorders. Gastroenterology 144: 1357-74 [PMID:23583734]

10. Ichikawa Y, Bayeva M, Ghanefar M, Potini V, Sun L, Mutharasan RK, Wu R, Khechaduri A, Jairaj Naik T and Ardehali H. (2012) Disruption of ATP-binding cassette B8 in mice leads to cardiomyopathy through a decrease in mitochondrial iron export. Proc. Natl. Acad. Sci. U.S.A. 109: 4152-7 [PMID:22375032]

11. Kim Y and Chen J. (2018) Molecular structure of human P-glycoprotein in the ATP-bound, outward-facing conformation. Science 359: 915-919 [PMID:29371429]

12. Krishnamurthy PC, Du G, Fukuda Y, Sun D, Sampath J, Mercer KE, Wang J, Sosa-Pineda B, Murti KG and Schuetz JD. (2006) Identification of a mammalian mitochondrial porphyrin transporter. Nature 443: 586-9 [PMID:17006453] 
13. Ksander BR, Kolovou PE, Wilson BJ, Saab KR, Guo Q, Ma J, McGuire SP, Gregory MS, Vincent WJ and Perez VL et al.. (2014) ABCB5 is a limbal stem cell gene required for corneal development and repair. Nature 511: 353-7 [PMID:25030174]

14. Morgan RE, Trauner M, van Staden CJ, Lee PH, Ramachandran B, Eschenberg M, Afshari CA, Qualls Jr CW, Lightfoot-Dunn R and Hamadeh HK. (2010) Interference with bile salt export pump function is a susceptibility factor for human liver injury in drug development. Toxicol. Sci. 118: 485-500 [PMID:20829430]

15. Oude Elferink RP and Paulusma CC. (2007) Function and pathophysiological importance of ABCB4 (MDR3 P-glycoprotein). Pflugers Arch. 453: 601-10 [PMID:16622704]

16. Pondarre C, Campagna DR, Antiochos B, Sikorski L, Mulhern H and Fleming MD. (2007) Abcb7, the gene responsible for $X$-linked sideroblastic anemia with ataxia, is essential for hematopoiesis. Blood 109: 3567-9 [PMID:17192398]

17. Pondarré C, Antiochos BB, Campagna DR, Clarke SL, Greer EL, Deck KM, McDonald A, Han AP, Medlock A and Kutok JL et al.. (2006) The mitochondrial ATP-binding cassette transporter Abcb7 is essential in mice and participates in cytosolic iron-sulfur cluster biogenesis. Hum. Mol. Genet. 15: 953-64 [PMID:16467350]

18. Seyffer F and Tampé R. (2015) ABC transporters in adaptive immunity.Biochim. Biophys. Acta 1850: 44960 [PMID:24923865]

19. Shintre CA, Pike AC, Li Q, Kim JI, Barr AJ, Goubin S, Shrestha L, Yang J, Berridge G and Ross £t al.. (2013) Structures of ABCB10, a human ATP-binding cassette transporter in apo- and nucleotide-bound states. Proc. Natl. Acad. Sci. U.S.A. 110: 9710-5 [PMID:23716676]

20. Stieger B. (2009) Recent insights into the function and regulation of the bile salt export pump (ABCB11). Curr. Opin. Lipidol. 20: 176-81 [PMID:19684528]

21. Tang L, Bergevoet SM, Bakker-Verweij G, Harteveld CL, Giordano PC, Nijtmans L, de Witte T, Jansen JH, Raymakers RA and van der Reijden BA. (2012) Human mitochondrial ATP-binding cassette transporter ABCB10 is required for efficient red blood cell development. Br. J. Haematol. 157: 151-4 [PMID:22085049]

22. Wilson BJ, Saab KR, Ma J, Schatton T, Pütz P, Zhan Q, Murphy GF, Gasser M, Waaga-Gasser AM and Frank NY et al.. (2014) ABCB5 maintains melanoma-initiating cells through a proinflammatory cytokine signaling circuit. Cancer Res. 74: 4196-207 [PMID:24934811] 